\title{
Rare Earth Elements- A Review
}

\section{Mubashir Mehmood*}

Institute of Geology, University of the Punjab, Lahore, Pakistan

*Corresponding author: Mubashir Mehmood, Institute of Geology, University of the

\section{Review Article}

Volume 2 Issue 2

Received Date: March 29, 2018

Published Date: April 11, 2018

DOI: $10.23880 /$ jenr-16000128

Punjab, Lahore, Pakistan, Tel: 00923153066061; Email: mubashirmehmood94@gmail.com

\section{Abstract}

This article presents a description of Rare-earth elements (REE) which are a collection of seventeen metals that have distinctive and varied chemical, magnetic, and luminescent properties that make them strategically important in a number of high-technology industries. Consequently, the REE are increasingly becoming more attractive commodity targets for the mineral industry. This paper presents a comprehensive review of the distribution, geological characteristics and resources of Australia's major REE deposits. REE are generally associated with igneous, sedimentary, and metamorphic rocks in a wide range of geological environments. Elevated concentrations of these elements have been documented in various heavy-mineral sand deposits (beach, dune, marine tidal, and channel), carbonatite intrusions, (per)alkaline igneous rocks, iron-oxide breccia complexes, calc-silicate rocks (skarns), fluorapatite veins, pegmatites, phosphorites, fluviatile sandstones, unconformity-related uranium deposits, and lignites. The dissemination and deliberation of REE in these deposits are influenced by various rock-forming processes including enrichment in magmatic or hydrothermal fluids, separation into mineral species and precipitation, and subsequent redistribution and concentration through weathering and other surface processes. The lanthanide series of REE (lanthanum to lutetium) and yttrium show a close genetic and three-dimensional association with alkaline felsic igneous rocks, however, scandium in laterite profiles has a closer empathy with ultramafic/mafic igneous rocks. The highest level of the cataloguing comprises four general 'mineral-system association' categories, regolith, basinal, metamorphic, and magmatic, which in turn contain sixteen 'deposit type' members, namely: regolith-carbonatite-associated; ultramafic/mafic rock-associated; basinal- heavy mineral sand deposits in beach, high dune, offshore shallow marine tidal, and tidal environments; phosphorite; lignite; unconformity-related; metamorphic -calc-silicate; and magmatic(per)alkaline rocks; carbonatite; pegmatite; skarn; apatite and/or fluorite veins; and iron-oxide breccia complex.

Keywords: REE; Metals; Distribution; Rocks; Environments

\section{Introduction}

The rare earth elements, often abbreviated as REEs, are a group of 17 elements including the lanthanides $\left(\mathrm{Z}^{1} / 457-\right.$
71), Sc and Y. They are extensively used in studies relating to the origin of volcanic rocks, sedimentology and processes in oceanography [1] and in particular the measurement of the $147 \mathrm{Sm} / 143 \mathrm{Nd}$ and $176 \mathrm{Lu} / 177 \mathrm{Hf}$ 


\section{Journal of Ecology \& Natural Resources}

isotopic systems are considered valuable tracers in environmental science [2]. REEs (mainly La, Eu, Gd, Tb and $\mathrm{Yb}$ ) extracted from mines are also employed in hightechnology applications, such as fluorescent lamps, radar screens and plasma displays as well as in auto exhaust absorption catalysts and high technology glasses [3]. Their determination in geological samples is therefore important for a number of scientific and commercial applications [4]. The chemical similarity of REEs, combined with their generally low amount and their presence as mixtures of rare earth minerals, makes their determination challenging and dependant on the extraction method and instrumental techniques used [5]. One of the most sensitive techniques available for the determination of REEs is the Instrumental Neutron Activation Analysis (INAA), a solid-sample technique considered to be of high accuracy and reliability and often referred to as a primary method [6]. INAA does not require a chemical pre-treatment of the samples and is particularly suitable for the characterisation of complex matrices such as the geological ones. Moreover, when measuring REEs only a few interferences, spectral and competitive nuclear reactions, are encountered, which makes this technique an appropriate choice [7]. The rare earth elements have long been recognised as useful because of their unusual chemical and physical properties. Their natural occurrence is strongly dependent on geological circumstances, and only in a few locations are they found in sufficient quantity and concentration, and in a suitable form and setting, to make their extraction and exploitation economically viable. The rare earth elements have also been of longstanding interest to geologists as tools for furthering scientific research into the origins of rocks and ores (Figure 1) and into the chemical behaviour of ocean waters. In recent years, the variety of high-tech applications of rare earth elements has burgeoned, especially in low carbon technologies, and demand for them has grown rapidly - a trend which is expected to continue. At the same time, there is international concern about the security of their future supply, their costs, and the impacts this might have [8]. In light of this increased interest, the Geological Society has decided to produce this briefing note, to help to inform debate among scientists, policy-makers, potential investors and other industry players. It is presented as a series of questions and answers that deal with the properties, occurrence, extraction, supply and uses of the rare earth elements. Our focus is on their geological aspects, and the relationship between these and other scientific, economic and political considerations - we have not attempted to address in detail these nongeological issues. It is intended to be read by nongeologists with an interest in the rare earth elements, and by geologists who do not specialise in this area. Some suggestions for further reading are provided at the end of the document, for those who wish to explore further.

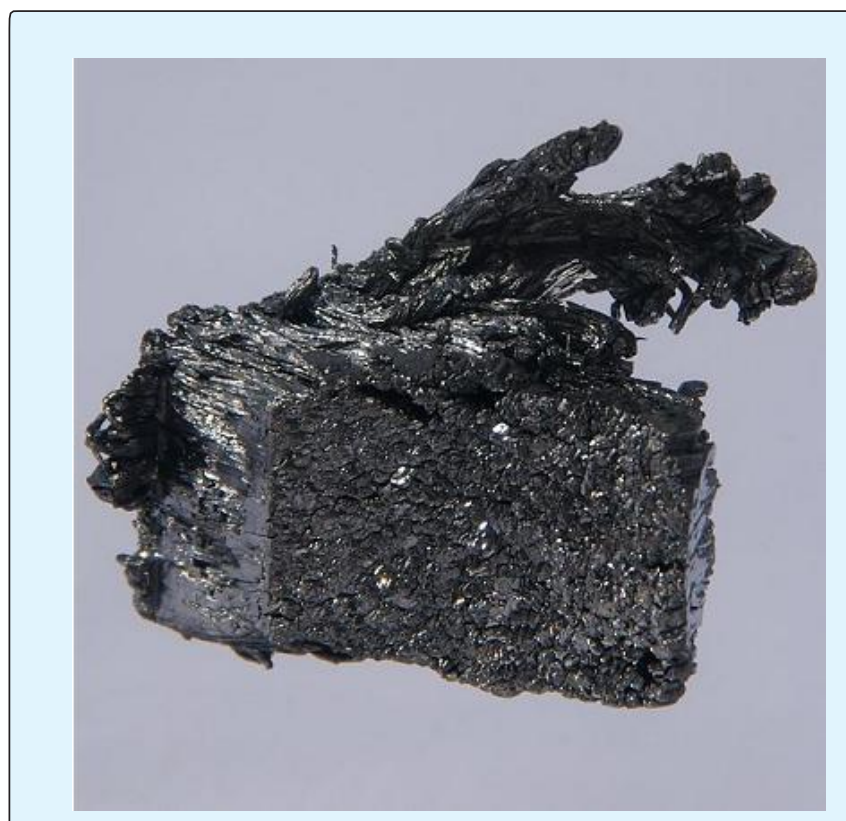

Figure 1: Ultrapure (99.997\%) crystalline Thulium, one of the rarest of the rare earth elements. Source [9].

\section{What are the Rare Earth Elements?}

Rare-earth elements (REE) are variously mentioned to as 'rare-earth metals (REM)', 'rare earths (RE)', 'rareearth oxides (REO)', and total rare-earth oxides (TREO). During recent times there has been much disagreement about the real number of elements comprised in the REE group. The International Union of Pure and Applied Chemistry has defined the REE as a group of seventeen chemically similar metallic elements that comprise the fifteen lanthanide elements (lanthanum to lutetium), scandium (Sc), and yttrium (Y) [10]. The latter two elements are classified as REE because of their similar physical and chemical properties to the lanthanides, and they are commonly related with these elements in many ore deposits. Chemically, yttrium resembles the lanthanide metals more closely than its neighbour scandium in the periodic table. The fifteen lanthanide elements have been further subdivided into the: light-rare earth elements (LREE) - lanthanum (La), cerium (Ce), praseodymium (Pr), neodymium (Nd), promethium (Pm), samarium $(\mathrm{Sm})$, and europium $(\mathrm{Eu})$; and heavy-rare-earth elements (HREE) gadolinium (Gd), terbium (Tb), dysprosium (Dy), holmium (Ho), erbium (Er), thulium (Tm), ytterbium (Yb), and lutetium (Lu) [11]. In some classifications the first seven lanthanide elements (La to Gd) are grouped as light REE and the rest (Tb-Eu) as heavy REE [12]. Crystal chemistry of monazite and 
xenotime (major REE-bearing phosphates) structures shows that monazite preferentially incorporates REE from $\mathrm{La}$ to $\mathrm{Gd}$, whereas xenotime tends to incorporate REE from Tb to Lu [12]. Despite its low atomic weight, yttrium (and scandium) is included with the HREE subgroup because its occurrence, ionic radius, and behavioural properties are closer to the HREE than to the LREE [13]. The LREE are generally more abundant, and less valuable than the HREE. Furthermore, REE with even atomic numbers are more abundant than their neighbours of odd atomic numbers because of their greater relative stabilities of atomic nuclei. Other classifications further divide the REE into Middle REE (MREE) comprising $\mathrm{Sm}, \mathrm{Eu}, \mathrm{Gd}, \mathrm{Tb}$, and $\mathrm{Dy}$, with the remainder of the elements from Ho to Lu, referred to as the HREE [14]. The rare earth elements (REE) are a group of seventeen metallic elements - the fifteen lanthanides, with atomic numbers 57 (lanthanum, La) to 71 (lutetium, $\mathrm{Lu})$, together with yttrium (Y, atomic number 39) and scandium (Sc, atomic number 21). All have similar chemical properties. The lower atomic weight elements lanthanum to samarium (Sm), with atomic numbers 57 to 62, are referred to as the light rare earth elements (LREE); while europium (Eu) to lutetium, with atomic numbers 63 to 71, are the heavy rare earth elements (HREE). (The dividing line drawn between LREE and HREE can vary somewhat, and the term 'mid REE' is also now sometimes used.) Yttrium, although it has a lower atomic weight, is grouped with the HREE because of its chemical similarity [15]. Scandium's properties are different enough from those of the other REE that most of the scientific and general literature excludes it and focuses on the lanthanides and yttrium - we have followed that convention here.

\section{Where are Rare Earth Elements Found?}

In looking for concentrations of any element that might be of economic interest, there are several factors to consider: the minerals in which they occur, and how easily the element can be extracted; the types of rock in which these minerals are found; the most promising geological settings in which to explore for these rocks; and the particular locations of mineral deposits which are capable of being mined and processed economically [16].

\section{In which Minerals do Rare Earth Elements Occur?}

Over 200 rare earth minerals have been described. However, in many cases there are no concentrations of these minerals that are economic to mine and in others there is no known method to extract the REE from the mineral economically. Minerals tend to be rich in either LREE or HREE, but generally include most of the REE in some quantity, if only at minor or trace levels. The proportions of the different REE within minerals vary between deposits. The name of a REE mineral often indicates, by use of the chemical symbol, the most abundant element. For example, in bastnäsite-(Ce), cerium is present in the largest quantity (it also contains significant amounts of lanthanum, neodymium and praseodymium) [16]. Bastnäsite- (Ce) is the most common but bastnäsite-(La) and bastnäsite-(Nd) also occur. (Chemical formulae are often written in an 'idealised form', with the mixture of REE represented by the dominant element. So, bastnäsite- (Ce) is given as $\mathrm{CeCO}_{3} \mathrm{~F}$.) The most important rare earth minerals in ore deposits are bastnäsite and monazite- $(\mathrm{Ce})\left(\mathrm{CePO}_{4}\right)$. Each contains about $70 \%$ rare earth oxides by weight. Other significant ones are the carbonates parisite-(Ce) and synchysite-(Ce) (often found intergrown with bastnäsite), and the phosphate xenotime-(Y). The complex silicates allanite-(Ce), eudialyite and steenstrupine also contain significant amounts of REE, as do the carbonate ancylite(Ce) and the phosphate churchite- $(\mathrm{Y})$. Minerals that contain much smaller amounts of rare earth elements can act as important sources (Figure 2). For example, the oxide loparite-(Ce), mined in Russia for its niobium, also contains about $1 \%$ rare earth oxide by weight - enough to make REE worthwhile extracting. Fluorapatite $\left(\mathrm{Ca}_{5}\left(\mathrm{PO}_{4}\right)_{3} \mathrm{~F}\right)$ can sometimes also be a source of rare earths. If mined as a source of phosphorus for fertiliser, it is possible to extract REE as a by-product.

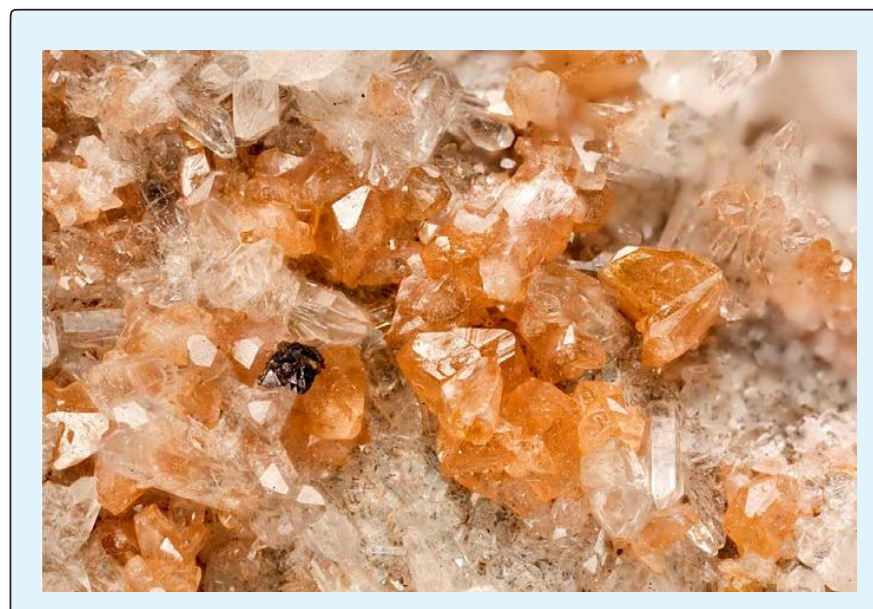

Figure 2: Monazite-(Ce) specimen from Siglo XX mine, Bolivia - the orange mineral is monazite, and the clear one quartz. Geological society of London report 2011.

\section{In which types of Rock do these Minerals Occur?}

REE are found principally in carbonatites. These are igneous rocks comprising more than $50 \%$ carbonate minerals, principally calcite (calcium carbonate), but in 
some cases magnesium-bearing carbonates (dolomite, magnesite) or iron-bearing carbonates (siderite), that crystallised from a high-temperature liquid from deep in the Earth. Carbonatites almost always contain REE, which constitute about 3,500 ppm of these rocks, so they are the most obvious place to look for REE. REE are found in high concentrations in some, but not all, alkaline igneous rocks (which make up only about $0.5 \%$ of all igneous rocks). They are characterised by their high contents of alkali metals. There are also some secondary deposits of REE. These are essentially produced by weathering of primary sources and their subsequent concentration by physical or chemical means. 'Placer' deposits are produced by physical concentration of rare earth and other heavy minerals from weathering; 'laterite' deposits result from enrichment of REE by in situ chemical alteration. There is one known example of a further type of secondary deposit, known as ion-adsorption clays, in China [16]. The REE in these deposits were released by weathering of REE-rich granites and subsequently adsorbed by clay minerals. There are also some rare earth mineral concentrations of economic interest in granite pegmatites and some hydrothermal (hot water) vein systems. Researchers have recently found elevated concentrations of REE in deep sea mud in the Pacific Ocean, which may also constitute a potential resource $[17,18]$.

\section{In what kinds of Geological Environment are these Rocks Found?}

The carbonatites and alkaline igneous rocks are characteristically found in the interiors of tectonic plates, that is, away from the active plate margins where volcanic activity is at its greatest. They are commonly associated with the major rift systems, such as the East African and Baikal rifts and the Rhine Graben. The carbonatites are mostly confined to continental areas, while the alkaline rocks also occur over much of the world's oceanic intraplate areas on volcanic islands. Although more than two thirds of carbonatites that have been dated are Phanerozoic in age (less than 500 million years), they are overwhelmingly concentrated in areas comprising older Precambrian rocks [19].

\section{What are the Environmental Effects of Rare Earth Production?}

The association of the radioactive elements thorium and uranium with REE deposits is one of the main environmental problems. The heavy REE in particular tend to concentrate in the same geological environments as thorium. A few percent of thorium by weight is common in monazite formed in granitic rocks, and in the mineral sands derived from them. These marine and alluvial placer deposits used to be the most important source of REE during the 1950s and 1960s. However, they have generally fallen from favour because of their radioactivity. Other deposits, such as those associated with carbonatite rocks, have much lower levels of thorium. In common with most mining and processing, REE production uses a great deal of energy. Where the energy is derived from fossil fuels, this will add to carbon emissions (in the absence of widespread Carbon Capture and Storage) - especially if much of it comes from coal fired power stations, as currently in China. Other environmental problems can arise from the extraction and processing of REE, including pollution from the chemicals used. These are often the result of inadequate environmental regulation or enforcement [20].

\section{Analytical Procedure}

Trace and rare earth elements concentrations were determined by inductively coupled plasma mass spectrometry (ICP-MS) using an Element X-series 2 at National Oceanography Centre Southampton (NOCS). Solutions for measurement by ICP-MS were diluted to appropriate total concentrations with a $3 \%$ nitric acid solution containing an internal spike with In-Re $(5 \mu \mathrm{g} \mathrm{kg}$ 1) and Be (20 $\left.\mathrm{g} \mathrm{kg}^{-1}\right)$ [21]. Artificial element standards were produced at $2,5,10,25,50,75,100,125,150,175$ and $200 \mu \mathrm{g} \mathrm{kg}^{-1}$ and used together with the internal spikes to calibrate the instrument and monitor sample drift corrections. All standard calibration curves display less than $3.5 \%$ analytical error with excellent linearity. International rock standards BHVO2, BIR1 and JB3, were run in triplicate as unknown to monitor accuracy of calibration with excellent reproducibility between triplicates. All analysis for trace and rare earth elements, $\mathrm{Mg}, \mathrm{Al}, \mathrm{Fe}$ and $\mathrm{Mn}$ are accurate and fall within the range of published recommended values. Sodium was measured in excess by $6 \%$ and $3 \%$ in BHVO2 and BIR1 respectively, whereas $\mathrm{Ca}$ and $\mathrm{Ti}$ concentrations were $3 \%$ below recommended range in JB3. Measurement reproducibility on international standards was also checked for discrepancies between standards prepared with and without ammonium oxalates to check for matrix effects from the oxalates. Standard dilution to daughter solutions were prepared by including ammonium oxalate matching the final concentration of $\left(\mathrm{NH}_{4}\right)_{2} \mathrm{C}_{2} \mathrm{O}_{4}$ in samples analysed by the ICP-MS [22]. Excellent reproducibility of results, showing less than $5 \%$ difference between standards with and without oxalates, indicates the absence of any matrix effects.

\section{Conclusions}

Rare earth elements will be of substantial attention for the foreseeable future, with demand likely to grow. While 
market mechanisms should ensure that serious shortages are averted, at least in the long term, there may be significant short-term disruptions to the supply of some REE, especially HREE, and price instability. Geological and mineralogical research should continue to play an important role in the search for rare earth ore deposits and their extraction, ensuring that as little damage is done to the environment as possible. With the renewed focus on REE by policy-makers and investors, in order that decision making is informed by the best available science, it is important to ensure sustained funding of research on the entire life cycle of the REE, from exploration and mining to manufacture, recycling, re-use and disposal. It is also essential to gather and maintain reliable and comprehensive information on REE geology, deposits, resources, reserves, production, trade and consumption.

\section{References}

1. Ghorbani Y, Becker M, Mainza A, Franzidis JP, Petersen J (2011) Large particle effects in chemical/biochemical heap leach processes - a review. Minerals Engineering 24(11): 1172-1184.

2. Fletcher WK (1981) Handbook of Exploration Geochemistry 1: Analytical Methods in Geochemical Exploration. In: Govett GJS (Ed.), Elsevier, Amsterdam, pp: 25-46.

3. Kim E, Osseo-Asare K (2012) Aqueous stability of thorium and rare earth metals in monazite hydrometallurgy: Eh-pH diagrams for the systems $\mathrm{Th}^{-}, \mathrm{Ce}^{-}, \mathrm{La}^{-}, \mathrm{Nd}^{-}\left(\mathrm{PO}_{4}\right)^{-}\left(\mathrm{SO}_{4}\right)^{-} \mathrm{H}_{2} \mathrm{O}$ at $25^{\circ} \mathrm{C}$. Hydrometallurgy 113-114, 67-78.

4. Santoro A, Thoss V, Ribeiro SG, Urgast D, Raab A, et al. (2016) Assessing rare earth elements in quartz rich geological samples. Applied Radiation Isotopes 107: 323-329.

5. Zawisza B, Pytlakowska K, Feist B, Polowniak M, Kita A, et al. (2011) Determination of rare earth elements by spectroscopic techniques: a review. J Anal Spectrom 26: 2373-2390.

6. Green DH (1958) Geology and petrology of Gray Creek area, Queensland. Bureau of Mineral Resources, Australia, Record 1958/110, pp: 59.

7. El-Taher A (2010) Rare earth elements content in geological samples from eastern desert, Egypt, determined by instrumental neutron activation analysis. Appl Radiat Isot 68(9): 1859-1863.
8. Jochum, KP, Nohl U, Herwig K, Lammel E, Stoll B, et al. (2005) Geo standards Geoanal.

9. (2011) Rare Earth Elements Profile, British Geological Survey.

10. Long KR, Van Gosen BS, Foley NK, Cordier D (2010) The principal rare earth deposits of the United Statesa summary of domestic deposits and a global perspective.

11. Walters A, Lusty P, Chetwyn C, Hill A (2010) Rare earth elements. Mineral Profile Series British Geological Survey, United Kingdom, pp: 45.

12. Ni Y, Hughes JM, Mariano AN (1995) Crystal chemistry of the monazite and xenotime structures. Am Mineral 80: 21-26.

13. Cooper W (1990) Queensland mineral commodity report. Queensland Government Mining Journal Department of Resource Industries, pp: 383389.

14. Hoatson DM, Jaireth S, Miezitis Y (2011) The horbani M, Mineral (2012b) Deposits and Natural Resources. Arian Zamin Publication, Tehran Major Rare-EarthElement Deposits of Australia: Geological Setting, Exploration, and Resources. Geoscience Australia, pp: 204.

15. Pourbaix M (1966) Atlas of Electrochemical Equilibria in Aqueous Solutions. Pergamon, NY, New York.

16. Abreu RD, Morais CA (2010) Purification of rare earth elements from monazite sulphuric acid leach liquor and the production of high-purity ceric oxide. Minerals Engineering 23(6): 536-540.

17. Michard A, Albarede F, Michard G, Minster JF, Charlou JL (1983) Rare earth elements and uranium in hightemperature solutions from East Pacific Rise hydrothermal vent field (13 N). Nature 303: 795-797.

18. Sverjensky DA (1984) Europium redox equilibria in aqueous solution. Earth Planetary Science Letters 67(1): 70-78.

19. Balashov YA, Ronov AB, Migdisov AA, Turanskaya NV (1964) The effect of climate and facies environment on the fractionation of the rare earth elements during sedimentation. Geochem Int 5: 951969.

20. DeBaar HJW, Bacon MP, Brewer PG, Bruland KW (1983) Rare earth distributions with a positive Ce 


\section{Journal of Ecology \& Natural Resources}

anomaly in the western Atlantic Ocean. Nature 301: 324-327.

21. Ellis TW, Schmidt FA, Jones LL (1994) Methods and Opportunities in the Recycling of Rare Earth Based Materials. The Metallurgical Society (TMS) conference on high performance composites.
22. Orris G, Grauch R (2002) Rare Earth Element Mines, Deposits and Occurrences. United States Geological Survey Open-File Report 02-189.

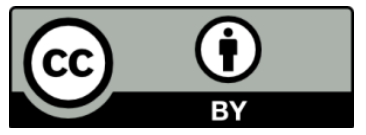

